\section{№. 4625 June 21,1958}

field work in archæology through the Council for British Archæology, and $£ 2,000$ has been earmarked for the preparation of a directory of local scientific societies, for which the British Association has accepted responsibility (see Nature, 181, 741 ; 1958). Other grants in the field of education include $£ 4,000$ over five years to the Scottish Women's Rural Institutes towards a programme of one-day and three-day schools and courses in various centres, at first on such subjects as public speaking, procedure at meetings, duties of office-bearers, etc. A similar grant over four years has been made to the York Academic Trust to establish in the Institute of Architectural Study, York, a national reference centre on the protection and repair of historic buildings, which will contain bibliographies, technical drawings, photographs, leaflets, exhibits and models on every aspect of the subject and will be equipped to deal with research, correspondence and personal inquiries. A major experiment which terminates in 1958 is the one-year course in applied social studies at the London School of Economics, but the course has so well justified itself that it has already been decided. to give training in generic case-work a regular place in the School's curriculum of professional training for social workers. Generic case-work courses have also been started in the Universities of Southampton and Birmingham.

Provision in aid of museums absorbed $£ 11,804$ of

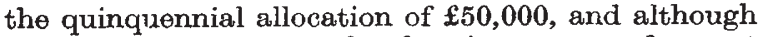
only $£ 328$ of this was for fees in respect of expert reports on twenty-seven museums, the benefits conferred appear far to outweigh the cost involved. Grants totalling $£ 8,560$ were offered in 1957 to seventeen museums to enable them to execute plans for re-organizing their collections and for improving the display of their material, and a grant of $£ 1,500$ was made to Trinity College, Dublin, to defray the cost of reorganizing the display of the "Book of Kells" as a centrepiece in the Long Room of the Library, with other exhibits suitably disposed. For pre-war village halls serving rural communities of not more than 1,000 people, the Trust has set aside $£ 100,000$ for re-equipment, and expenditure in 1957 amounted to $£ 3,233$. Nine applications for film projectors for crofting communities served by the Highlands and Islands Film Guild were approved during the year, and $£ 5,000$ to be disbursed over five years has been allotted in support of an effort by the National Council of Social Service and by rural community councils to strengthen the citizens' advice bureaux already run by the councils, to estab. lish bureaux in small country towns and link these with the countryside, and to encourage experiments. A sum of $\$ 5,500$ over two years has been allotted for training six people each year for full-time community centre wardenship. Financial interest in family service units in 1957 was limited to training social workers in such techniques, and to research in which good progress was made with inquiries into problems of families with handicapped children. $£ 3,000$ was granted to the Scottish Epilepsy. Association for its workshop scheme.

\title{
THE SMITHSONIAN INSTITUTION
}

\section{REPORT FOR 1956-57}

T WE report of the Secretary of the Smithsonian Institution for the year ended June 30, 1957*, to which are appended the financial report of the Executive Committee of the Board of Regents, and reports on the library and on publications and on branches of the Institution, makes special reference to the functions of the Institution as a museum. The United States National Museum, the National Collection of Fine Arts, the Freer Gallery of Art, the National Air Museum, the National Zoological Park and the National Gallery of Art all contain public exhibits, and as a group these Smithsonian units care for the great national collections of the United States, constituting one of the largest and most distinguished groups of cultural and scientific collections in the world.

Much progress was made during the year in the work of the United States National Museum, and when the new Museum of History and Technology now being planned is completed it will be one of the world's finest museum buildings. Plans for new wings for the overcrowded Natural History Building were also included in the 1958 appropriation, and the modernization of the public displays of the Institution continued during the year. Some progress is reported in the collections and facilities of the National Zoological Park, which is still inadequately housed. The calendar year 1956 marked a peak in

- Smithsonian Institution. Report of the Secretary and Financial Report of the Executive Committee of the Board of Regents for the year ended June 30,1957 . Pp. $x+204+9$ plates. (Smithsonian Publication 4308.) (Washington, D.C.: Government Printing Office,
1958.) the activities of the Biosciences Information Exchange, which, operating within the Smithsonian, acts as a clearing house for current research in the biosciences and now covers 14,000 active research projects.

Accessions to the National Museum during the year totalled 647,750 specimens, and field-work was conducted in Bermuda, Brazil, Canada, Ecuador, Europe, Mexico, Panama, Peru, the Philippines and Society Islands, and many parts of the United States. These included field studies of the flora of southern Brazil, researches on the distribution and variation of the bird-life of the Isthmus of Panama, marine studies at the Bermuda Biological Station, and inquiries by Dr. D. J. Price for suitable nineteenth-century chemical and physical laboratory apparatus to illus. trate the history and principles of these sciences in the displays now being planned for the new exhibit halls as well as regarding early scientific instruments.

The Bureau of American Ethnology's systematic researches during the year included archæological reconnaissance in Ecuador, studies of museum collections in Europe of Mesolithic materials for their possible bearing on the Eskimo problem, and studies of the Florida Seminole and among the Seneca. The River Basins Survey continued its programme for salvage archæology and by the end of the year 350 sites in forty-seven reservoir basins in eighteen States had been excavated, and the Missouri Basin Project alone had eatalogued 749,244 specimens from 1,725 numbered sites and fifty collections not assigned site numbers. The manuscript collections of the Bureau 
continued to be used by archæologists and others, and utilization of the Bureau's photographic collections increased.

The Astrophysical Observatory continued its researches in solar astrophysics as well as its meteorite studies, greater emphasis being given to the broader scientific investigation of phenomena in the solar system, and stress is laid on the Observatory's 'Moonwatch' programme-the optical tracking of the Earth satellites launched as part of the International Geophysical Year. Careful statistical studies were made of the variation of solar radiation intensity ; theoretical studies were made of the propagation of non-adiabatic acoustic waves in the solar atmosphere, and the theory of non-steady phenomena in the solar atmosphere and corona was investigated. The study of the ablation of meteorites was concerned with the distinct shapes and surface features of meteorites and the examination of the internal structure from a metallurgical point of view.

The Division of Radiation and Organisms continued its work on the role of light in regulating growth in plants, including photomorphogenesis, phototropism, chloroplast development, photoperiodic chlorosis, and the modification of $\mathrm{X}$-ray damage by visible radiant energy.

During the year, 1,050 specimens were added to the National Air Museum, and increasing requests are being received for information on aeronautical history and progress. Accessions to the National Zoological Park, which covers 176 acres, numbered 1,851 , but 2,965 were removed by death, exchange or return to depositors, and the net count at the close of the year was 3,157. Visitors are estimated at almost four million. Although veterinary work was curtailed, a co-operative study was undertaken on aspergillosis in birds to determine the best method of artificial infection and the mode of natural transmission, to develop a sensitivity test or other method for early diagnosis, and to discover the most efficacious method of treatment.

Visitors to Barro Colorado Island totalled 750 , including sixty-one scientists using the station's facilities of special researches, particularly in observation of wild fowl, forest ecology, photography and studies of insects. The International Exchange Service handled 1,205,039 packages of Government, scientific and literary publications, an increase of 43,184 on the previous year. The Smithsonian Library received 54,316 publications during the year ; 1,110 volumes were issued on inter-library loans to 116 Government and other libraries throughout the country, and 13,000 reference questions were answered. Eighty new Smithsonian publications were issued during the year and 405,266 copies of publications and miscellaneous items were distributed.

\section{THE NATIONAL SCIENCE FOUNDATION}

$\mathrm{T}$ HE seventh annuel report of the National Science Foundation for the year ended June 30, 1957*, includes a foreword from the chairman of the National Science Board, Dr. D. W. Bronk, and the Director's statement, to which are appended the financial report, particulars of membership of the Board, its staff, committees and advisory panels, lists of publications and of research grants and fellowship awards. The programme activities of the Foundation, on which expenditure was 664,561 dollars, included a continued survey of the United States effort in research and development, most of the initial series of studies for which were completed during the year. A further survey of the industry sector for 1955 and 1956 is now being conducted. The report also summarizes the findings of a survey of Federal financial support of research facilities and equipment, which recommended that while Federal support for operation and management is sometimes unavoidable, ideally it should be confined to establishment and construction costs and conditional on participation by recipient institutions and other bodies concerned and on the availability of competent scientific man-power.

An advisory panel on the status of high-energy nuclear research in the United States recommended that the U.S. Government should continue its active support of high-energy physies, including the design, construction and operation of, and experiment with, high-energy accelerators ; in particular, extension of the support given by the Department of Defence and the National Science Foundation was recommended. Expenditure on high-energy accelerators is estimated to reach 60-90 million dollars a year by 1962 and

- National Science Foundation, Washington. Seventh Annual Report for the Fiscal Year ended June 30, 1957. Pp. xix +279. this level is believed to be essential. The need for accelerators of varied types should be recognized, the most important parameters being energy, intensity and kind of particle, and it is usually preferable to extend the range of these parameters rather than to increase the number of functionally similar accelerators. Research and development on new types of accelerators should be adequately supported, and especially efforts should be made to increase the energy limit. Proposals for the location of new accelerators should be reviewed on their merits, having regard to the research contemplated, the stimulus to science and the opportunities for training. An Advisory Committee on Minerals Research through various subcommittees concluded that much new co-ordinated research was required in geology, geochemistry and geophysics to pursue mineral exploitation scientifically. To determine the scale, distribution and character of this research, all existing data on mining districts should first be re-examined and synthesized to avoid duplication of effort or omission of fundamential studies. This programme requires the continuing participation of all existing agencies; the establishment of a Minerals Research Institute was also recommended, to conduct, co-ordinate and assimilate fundamental research in fields of science related to the formation of mineral deposits and disseminate the results of such research activities. This Institute should be supported and maintained largely by the mining companies. During the year the Foundation completed the transfer to the Office of Technical Services of the Department of Commerce of all research and development reports on synthetic rubber. The Foundation reported favourably on a proposal to establish a geophysical institute as part of the University of Hawaii, but Federal funds should 